\title{
Effect of Spacing and Different Levels of Nitrogen on Growth Parameters in Red Cabbage (Brassica oleracea var. Capitata sub-var. Red Ruby)
}

\author{
Sarvesh Kumar Tiwari ${ }^{1 *}$, Jagdish Prasad Singh ${ }^{2}$, Mausam Tarrang Tigga ${ }^{3}$, \\ Pushpendra Singh ${ }^{4}$ and Dharambir Dhan ${ }^{5}$
}

\author{
${ }^{1}$ Iffco Kisan Sanchar Limited, Ministry of Agriculture and Farmer's Welfare, India \\ ${ }^{2}$ Department of Horticulture, SHUATS formerly Allahabad Agricultural Institute-Deemed \\ University, Allahabad (U.P.), India \\ ${ }^{3}$ Department of Soil Science, Sam Higginbottom University of Agriculture, Technology and \\ Sciences, Allahabad (U.P.), India \\ ${ }^{4}$ Zila Parishad Krishi Mahavidhyalaya, Banda (U.P.), India \\ ${ }^{5}$ Soil Conservation, Department of Agriculture Cooperation and Farmer's Welfare, India \\ *Corresponding author
}

\section{A B S T R A C T}

\begin{tabular}{|l|}
\hline K e y w o r d s \\
Red cabbage, Spacing \\
cum nitrogen trial, \\
Growth parameter, \\
Brassica oleracea, \\
Biological yield.
\end{tabular}

Keywords

Red cabbage, Spacing

cum nitrogen trial,

Growth parameter,

Brassica oleracea

\section{Introduction}

India's diverse climate ensures availability of all varieties of fresh vegetables and ranks second in the world. Among all vegetables cabbage is an important vegetable sown in rabi season. It includes 1.4 gram protein, 0.2 gram fat, 5.7 gram carbohydrate and Vitamin A, B, C, E in sufficient amount. Rather iron, calcium, magnesium and sodium elements in abundance. Vista taste of cabbage is found due to presence of sinigrin glucoside which helps indigestion. In India, cabbage is grown in large areas having a cool and moist climate (NHB).

The major cabbage producing states in India are Uttar Pradesh, Orissa, Bihar, Assam, West Bengal, Maharashtra and Karnataka.

For obtaining high yield of cabbage crop, soil health is a critical factor and with this point in 
view the investigation took place with following objectives:

To standardize the most appropriate spacing of red cabbage.

To ascertain the most appropriate nitrogen level for higher productivity.

In the present age of modern technology, more emphasis is given to the higher plant densities with closer spacing to increase marketable yield per unit area. Spacing of the plant largely depend on the variety and soil fertility, spacing to meet market demand can regulate the size of the head spacing exercise a dominant influence on growth and yield of most of the leafy vegetables.

To maintain the plant population, spacing either in row to row or between the plants in rows is very important. In closer spacing more number of plants per unit area can be accommodated, which results into higher production per unit area where as wide spacing facilitates better growth for each plant.

\section{Materials and Methods}

The investigation entitled "Spacing Cum Nitrogen trail in Red Cabbage" was carried in the department of Horticulture, SHUATS, formerly SHIATS, Allahabad (Allahabad Agricultural Institute, Deemed-University)

With 3 categories of spacing i.e. $45 \times 30 \mathrm{~cm}$, $45 \times 45 \mathrm{~cm}$ and $45 \times 60 \mathrm{~cm}$ respectively; 12 treatments were combined with 4 different levels of Nitrogen i.e. $0 \mathrm{~kg} / \mathrm{ha}, 60 \mathrm{~kg} / \mathrm{ha}$, $120 \mathrm{~kg} / \mathrm{ha}$ and $180 \mathrm{~kg} / \mathrm{ha}$ with treatment spacing $45 \times 30 \mathrm{~cm}+$ Nitrogen $0 \mathrm{~kg} / \mathrm{ha}\left(\mathrm{T}_{1}\right)$, spacing $45 \times 30+$ Nitrogen $60 \mathrm{~kg} /$ ha $\left(\mathrm{T}_{2}\right)$, spacing $45 \times 30 \mathrm{~cm}+$ Nitrogen $120 \mathrm{~kg} / \mathrm{ha}\left(\mathrm{T}_{3}\right)$, spacing $45 \times 30+$ Nitrogen $180 \mathrm{~kg} /$ ha $\left(\mathrm{T}_{4}\right)$, spacing $45 \times 45+$ Nitrogen $0 \mathrm{~kg} / \mathrm{ha}\left(\mathrm{T}_{5}\right)$, spacing $45 \times 45 \mathrm{~cm}+$ Nitrogen $60 \mathrm{~kg} / \mathrm{ha}\left(\mathrm{T}_{6}\right)$, spacing $45 \times 45 \mathrm{~cm}+$ Nitrogen $120 \mathrm{~kg} / \mathrm{ha}$ $\left(\mathrm{T}_{7}\right)$, spacing $45 \times 45 \mathrm{~cm}+$ Nitrogen $180 \mathrm{~kg} / \mathrm{ha}$ $\left(\mathrm{T}_{8}\right)$, spacing $45 \times 60 \mathrm{~cm}+$ Nitrogen $0 \mathrm{~kg} / \mathrm{ha}$ $\left(T_{9}\right.$ ), spacing $45 \times 60 \mathrm{~cm}+$ Nitrogen $60 \mathrm{~kg} / \mathrm{ha}$ $\left(\mathrm{T}_{10}\right)$, Spacing $45 \times 60 \mathrm{~cm}+$ Nitrogen 120 $\mathrm{kg} / \mathrm{ha}\left(\mathrm{T}_{11}\right)$ and spacing $45 \times 60 \mathrm{~cm}+$ Nitrogen $180 \mathrm{~kg} / \mathrm{ha}$; respectively were designed with R.B.D. in which total number of plots taken were 36 and total plants in experimental field was taken 815 in which net length and width of each plot was 4.80 meter and 0.90 meter, respectively.

The experiment field was prepared by ploughing with a tractor drawn disc plough followed by two cross harrowing and planking. The field was thoroughly leveled by a leveler before it was laid out to find out economical yield, biological yield and total yield at different spacing-cum-nitrogen level as per method of analysis of variance (Panse and Sukhatme, 1967).

\section{Results and Discussion}

The results of the investigation, regarding the influence of spacing, nitrogen and their interaction on growth and yield of red cabbage have been presented below:

Plant Height $(\mathrm{cm})$

Number of leaves per plant

Diameter of main stem

The plant height as influenced by different treatments was recorded at 30, 45, 60 and 75 DAT and presented in Graph 1. At 30 DAT the effect of spacing, nitrogen levels and their interaction significantly influenced the plant height of red cabbage var. Red Ruby.

Graph 1 clearly revealed that as far as interaction between spacing and nitrogen levels is concerned; the maximum plant yield height $(31.22 \mathrm{~cm})$ was with $\mathrm{T}_{4}\left(\mathrm{~S}_{1} \mathrm{~N}_{3}\right.$ i.e. 
spacing of $45 \times 45 \mathrm{~cm}+180 \mathrm{~kg} \mathrm{~N} /$ hectare), followed by $\mathrm{T}_{3}\left(\mathrm{~S}_{1} \mathrm{~N}_{2}\right.$, i.e. spacing of $45 \times 45$ $\mathrm{cm}+120 \mathrm{~kg} \mathrm{~N} /$ hectare) with $30.89 \mathrm{~cm}$ and the minimum $26.33 \mathrm{~cm}$ remained with $\mathrm{T}_{9}$ $\left(\mathrm{S}_{3} \mathrm{~N}_{0}\right.$ i.e. spacing of $45 \times 60 \mathrm{~cm}+0 \mathrm{~kg} \mathrm{~N} /$ hectare). Majority of interacting combinations between the 3 spacing and 4 Nitrogen levels resulted in taller plants than the other interacting combination. However, maximum plant height was observed at this stage of growth with $\mathrm{S}_{1} \mathrm{~N}_{3}$.

Abundant nitrogen supply and its availability helped the red cabbage plants to attain more vigour in terms of plant height than lower $\mathrm{N}$ levels as well as control. The plant height reduced with wider spacing might have been due to availability plant nutrient and sunlight to each plant. Spreading Red Cabbage responded positively to upward red cabbage than wider spacing.

However, the interaction between the 3 spacing and 4 nitrogen level at all successive stages of growth, i.e. 30, 45, 60 and 75 DAT, remained highly significant, i.e. influencing the plant height, shorter spacing and higher nitrogen levels significantly increased the plant height because of enough availability of nitrogen at growing stages which gave least competition and resistance. Similar results have been reported by Gardner and Roth, 1989 and Sharma, 2001. The number of leaves per plant as influenced by different treatments, was recorded at 30, 45, 60 and 75 DAT, and presented in graph at $30 \mathrm{DAT}$, the effect of spacing, nitrogen levels and their interaction was non-significant on number of leaves per plant. However, at 45, 60 and 75 DAT, spacing, nitrogen levels and their interaction was non-significant on number of leaves per plant. However, at 45, 60 and 75 DAT, spacing, nitrogen levels and their interaction significantly influenced the number of leaves per plant of red cabbage var. Red Ruby.

The Graph 2 clearly revealed that as far as interaction between spacing and nitrogen levels are concerned; the maximum number of leaves per plant (14.67) was with $\mathrm{T}_{4}$, followed by 14.56 at $\mathrm{T}_{3}, 14.0$ at $\mathrm{T}_{2}, \mathrm{~T}_{1}$ with $13.56, \mathrm{~T}_{8}$ with $13.22, \mathrm{~T}_{7}$ with $13.0, \mathrm{~T}_{6}$ with 12.33 and $\mathrm{T}_{5}$ with $12.33,11.89$ with $\mathrm{T}_{11}$ and 11.67 at $\mathrm{T}_{10}$, whereas the minimum 11.22 remained with $\mathrm{T}_{12}$.

Graph.1 Plant height as influenced by different treatments

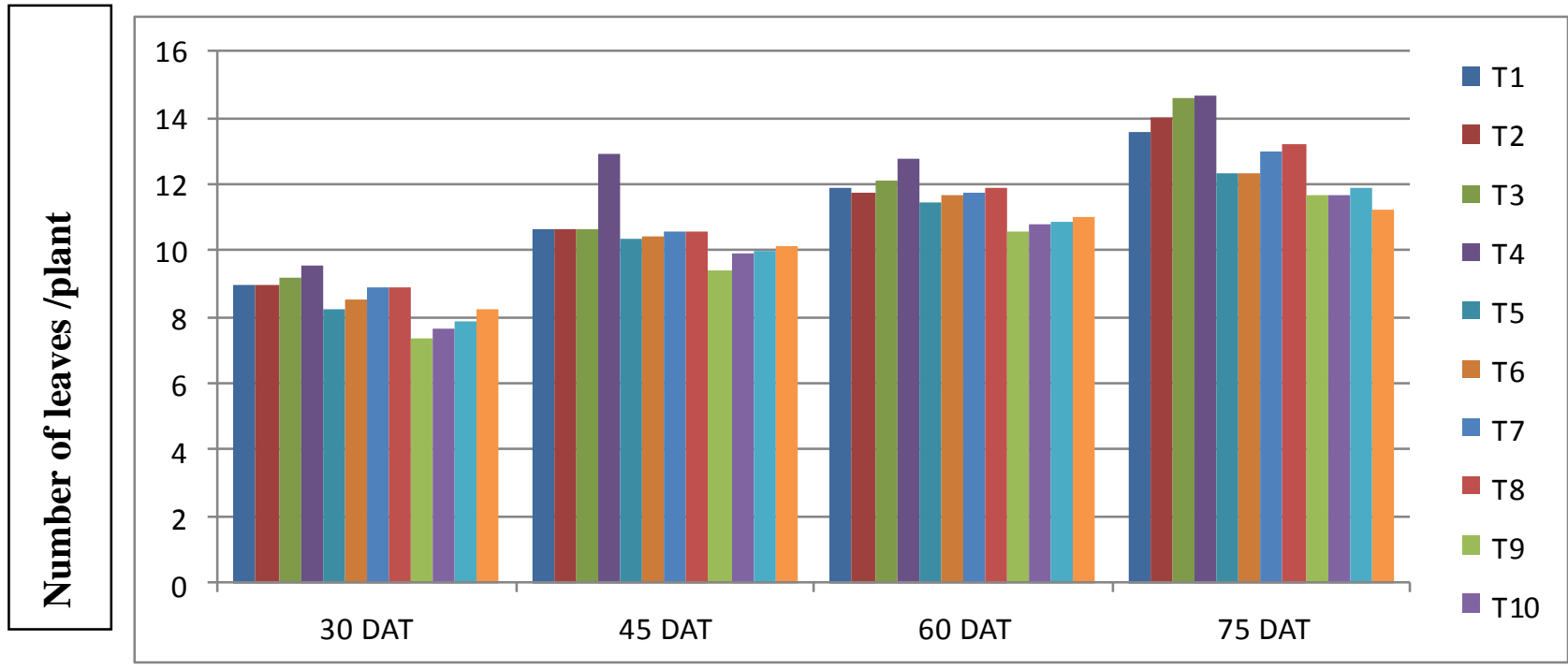


Graph.2 Interaction between spacing and nitrogen levels

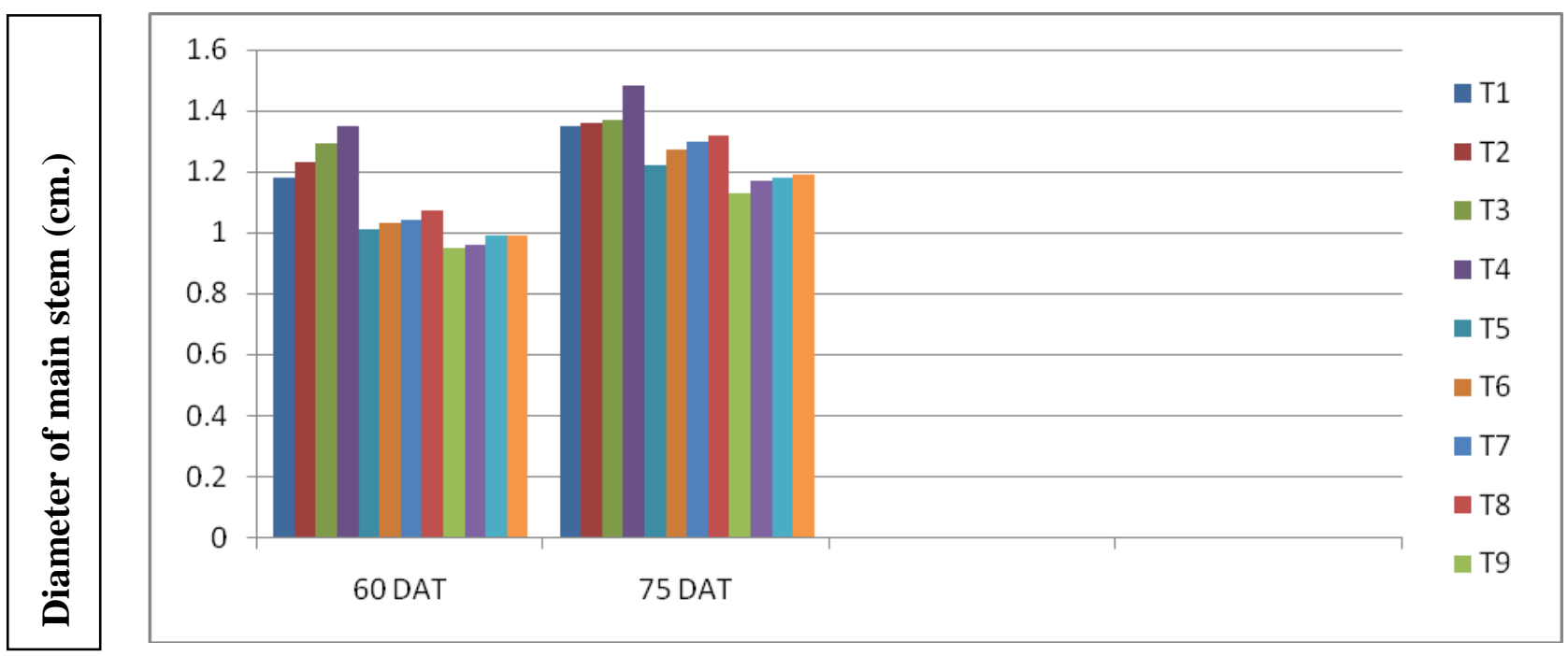

Graph.3 Influence of treatments on diameter of main stem of red cabbage var. Red Ruby

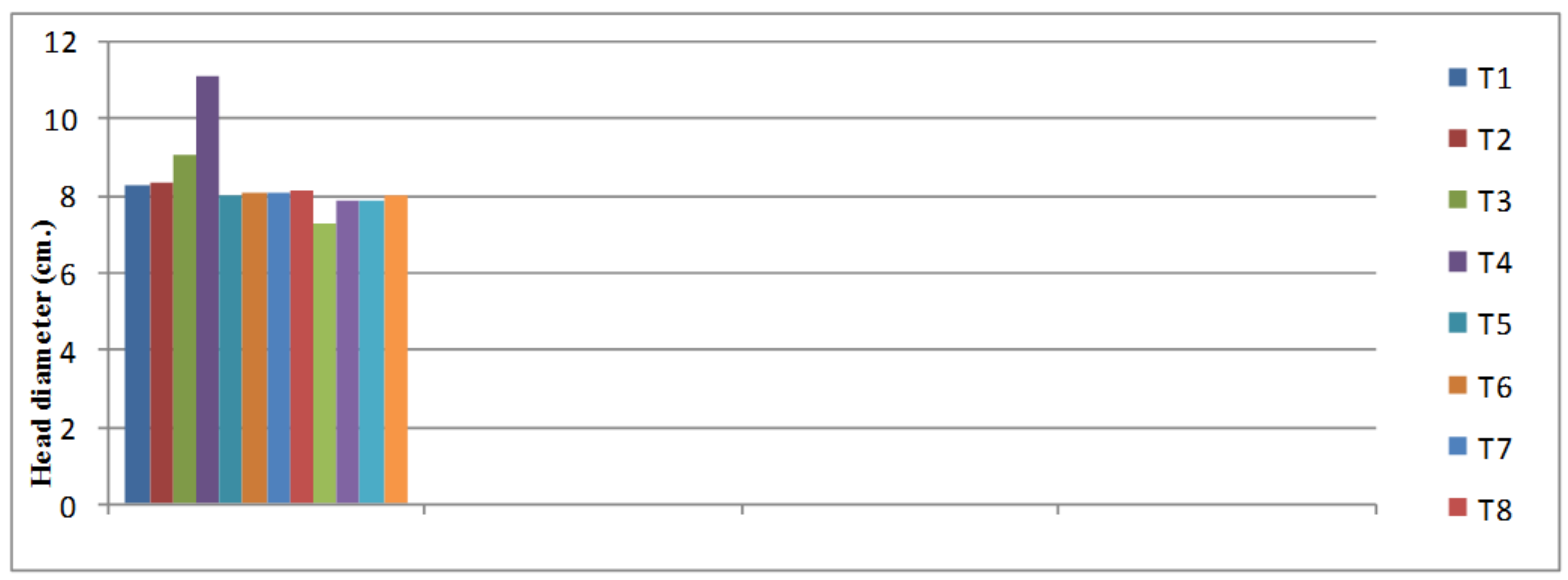

Maximum number of leaves per plant was observed at this stage of growth with $\mathrm{S}_{1} \mathrm{~N}_{3}$ closely followed by $\mathrm{S}_{1} \mathrm{~N}_{2}$. Extreme accessibility of nitrogen to the red cabbage plants must have played positively for more leaves per plant, as adequate supply of nitrogen helped in root proliferation, thus helping in better assimilation of nitrogen by red cabbage plants. Vigier and Cutcliffe (1985) also reported similar findings with higher nitrogen level.

The Graph 3 suggest that all the three treatments i.e. spacing, nitrogen levels significantly influenced the diameter of main stem of red cabbage var. Red Ruby, at both the successive of growth i.e. at 60 and 75 DAT.

Graph 3 clearly revealed that as far as interaction between spacing and nitrogen levels at 75 DAT are concerned; the maximum stem diameter $(1.48 \mathrm{~cm})$ was with $\mathrm{T}_{4}$, followed by $\mathrm{T}_{3}$ with $1.37 \mathrm{~cm}, \mathrm{~T}_{2}$ with 1.36 $\mathrm{cm}, \mathrm{T}_{1}$ with $1.35 \mathrm{~cm}, \mathrm{~T}_{8}$ with $1.32 \mathrm{~cm}, \mathrm{~T}_{7}$ with $1.30 \mathrm{~cm}, \mathrm{~T}_{6}$ with $1.27 \mathrm{~cm}, \mathrm{~T}_{5}$ with $1.22 \mathrm{~cm}$, $\mathrm{T}_{12}$ with $1.19 \mathrm{~cm}, \mathrm{~T}_{11}$ with $1.18 \mathrm{~cm}, \mathrm{~T}_{10}$ with $1.17 \mathrm{~cm}$, whereas the minimum $1.13 \mathrm{~cm}$ 
remained with $\mathrm{T}_{9}$. Majority of interacting combinations between the three spacing and four nitrogen levels resulted in significantly sturdier stem diameter than the other interacting combinations. However, maximum stem diameter was with $\mathrm{S}_{1} \mathrm{~N}_{3}$ followed by $\mathrm{S}_{1} \mathrm{~N}_{2}$.

High availability of nitrogen and shorter spacing between the plants must have helped the plant in attaining greater stem diameter. Trembley (1989) reported similar results with Brassica oleracea spp. Italica cv. Green Valiant.

In view of findings and results presented above, it may be concluded that the 3 spacing tried here, $\mathrm{S}_{1}$ significantly dominated others, and of the four nitrogen levels tried $\mathrm{N}_{3}$ was found to be significantly in all the growth parameters of the 12 treatment combinations, $\mathrm{S}_{1} \mathrm{~N}_{3}$ emerged as significantly best interaction for growth capacity of red cabbage var. red ruby.

\section{Acknowledgments}

Authors are thankful to the department of horticulture, AAIDU, for providing their knowledge and help meet out the difficulties while conducting the research.

\section{References}

Gardner, B. R. and Roth, R. L. (1989). Mid rib nitrate concentration as a means for determining nitrogen needs of broccoli. Journal of plant nutrition, 12(1): 111123.

Panse, V. G. and Sukhatme, P. V. (1967). Statistical method for ATL methods for agricultural works, ICAR New Delhi $2^{\text {nd }}$ edition. Pp. 381.

Sharma, K. C. (2001). Response of fertility and spacing to seed production of Chinese cabbage (Brassica comprestris sub - Sp. Pekinensis) under north western Himalayas. Indian Journal of Agricultural Sciences, 71 (9): 608-609.

Trembley, N. (1989). Effect of nitrogen forces and rates on yield and hollow stem development in broccoli. Canadian Journal of Plant Science, 79 (1): 149151.

Vigier, B. I. and Cutcliffe, J. A. (1985). Effect of nitrogen on the incidence of hollow stem in broccoli. Acta-Horticulturae, 157: 303-308.

\section{How to cite this article:}

Sarvesh Kumar Tiwari, Jagdish Prasad Singh, Mausam Tarrang Tigga, Pushpendra Singh and Dharambir Dhan. 2017. Effect of Spacing and Different Levels of Nitrogen on Growth Parameters in Red Cabbage (Brassica oleracea var. Capitata sub-var. Red Ruby). Int.J.Curr.Microbiol.App.Sci. 6(12): 2927-2931. doi: https://doi.org/10.20546/ijcmas.2017.612.340 